4 Shinn, F. A., J. Sediment. Petrol., 22, 291 (1963).

- Newell, N. D., Imbrie, J., Purdy, I. G., and Thurber, D. I., Bull. Amer. Mus. Nat. Hist., 117, 177 (1959)

- Kornicker, L. \$., Bonet, F., Oann, R., and Hoskin, O. M., Publ. Inst. Mar. Sei. Cong., 8, 929 (1957).

' Hiatt, R. W., Proc. Eighth Pacific Cong., 3, 929 (1957).

- Wiens, H. J., Atoll Enviromment and Ecology (Yalo University Press, New Haven, 1962.)

- Yonge, O. M.s, in Russell, F. \$., Advances in Marine Biology (Academic Press, New York, 1963)

10 Tracey, J. I., Iadd, H. S., and Hoffmeister, J. F., Bull. Geol. Soc. Amer. 59,861 (1948).

21 Wells, J. W., Mem. Geol. Sac. Amer., 67, 609 (1957).

12 Stoddart, D. R., Biol. Rev., 44, 438 (1969).

18 Greig-Smith, P., Quantitative Plant Ecology, second ed. (Butterworths, London, 1964).

u Kershaw, K. A., Quantitative and Dymamic Ecology (Flsevier, New York, 1964).

\section{Strontium-Isotope Evidence for Marine or Freshwater Origin of Fossil Dipnoans and Arthrodires}

STRONTrUM has a uniform isotopic composition in well mixed regions of the $\mathbf{s e n}^{1,2}$ because of its long residence time. Though the strontium isotope composition of seawater has fluctuated through the Phanerozoic ${ }^{8}$, it appaxently has been relatively homogeneous during particulex periods of time. Marine organisms that utilize calcium (and strontium) in their shells or skeletons are known to incorporate strontium of marine isotopic composition. Strontium in fresh or brackish water may diverge isotopically from the marine value, depending principally on the age and $\mathrm{Rb} / \mathrm{Sr}$ ratio of source rocks that contribute soluble strontium. Thus the isotopic composition of strontium in fossil aquatic organisms may rule out a marine origin for the organisms, provided that the age of the organisms is known, and the isotopic composition of the fossil has not been perturbed by strontium addition or exchange; on the other hand, the isotopic data may be consistent with (but not prove) a marine origin. Nonequilibrium of strontium in phosphate and strontium in carbonate (or seawater) during diagenesis may be inferred from a lack of microscopically detectable alteration, and by analogy with the non-equilibrium of certain claycarbonate systems 5 .

A vexing biological problem has been the marine or freshwater habitat of many early and middle Palaeozoic fishes ${ }^{6,7}$. In addition to the difficulty in distinguishing sediments of freshwater, marine and brackish environments, fishes found preserved in rocks of undoubted marine origin may not have been entirely marine in habit; they may have been freshwater types transported by rivers into the sea either alive or as cadavers, or they may have been euryhyaline, returning to the rivers to spawn. The Dipnoi (lungfishes) have a special interest in this connexion. For various physiological reasons and because it seems reasonable to believe that "Iungs in fishes are an adaptation for life in poorly oxygenated waters . . such as are unlikely in the sea..."9, the Dipnoi have been considered by most zoologists to be of fresh-water origin. The earliest known lungfish are, however, Dipnorhynchus from the marine Hunsrückschiefer of Germany and Taemas Group of New South Wales, and Uranolophus from the "marginal marine" Beartooth Butte Formation of Wyoming. This evidence has been used to support a marine origin for dipnoans.

At Wee Jasper, New South Wales, Dipnorhynchus (or a close relative) occurs in the upper Ermsien or lower Eifelian (Lower-Middle Devonian) Receptaculites Limestone of the Taemas Group in association with numerous arthrodires (Placodermi), particularly Buchanosteus. The invertebrates in these limestones clearly indicate a marine environment, and there is strong independent stratigraphic evidence that the fish were not washed in ${ }^{9}$. Further, it is generally agreed that though the arthrodires probably originated in freshwater, at least some of them had adapted to marine conditions before the end of the early Devonian. Hence it is not surprising to find the group well represented at this locality.

Samples of Buchanosteus and Dipnorhynchus and associated carbonate from Wee Jasper were collected for analysis. The sedimentary rocks and fossils show no sign of metamorphism or other alteration, either in the field or in thin section. The delicate structure of the bone is well preserved in the rock; the few complete skulls that have been found also show little deformation.

Representative phosphate-free samples of carbonate were dissolved in $1 \mathrm{~N} \mathrm{HCl}$ and strontium for isotopic analysis was obtained from the detritus-free supernate. Insoluble residues amounted to less than 2 per cent of the samples. Phosphate from the two fish was cleaned of carbonate by leaching in $1 \mathrm{~N}$ HCl. X-ray diffraction of the phosphate shows lines which are largely apatite or a related phosphate. No evidence of carbonate, or detritus such as feldspar or clay, was detected in the analysed phosphate samples. Amounts of rubidium and strontium were determined on whole-rock carbonate and on the carbonate-free phosphate by X-ray fluorescence. Strontium was separated from the samples by dissolution and standard ion exchange techniques and isotope composition was determined with a 6-inch, Nier-type mass spectrometer. Results are listed in Table 1. Because of the low $\mathrm{Rb} / \mathrm{Sr}$ ratios and the moderate age of the strata, measured ${ }^{87} \mathrm{Sr} /{ }^{86} \mathrm{Sr}$ ratios are essentially initial ratios, or ratios at time of deposition.

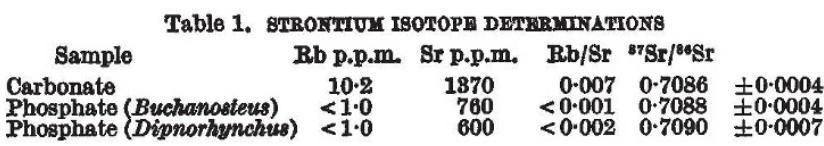

The ${ }^{87} \mathrm{Sr} /{ }^{88} \mathrm{Sr}$ ratios are identical within the analytical uncertainties, and are consistent with the view that the skeletons of both types of fish were formed while the fish inhabited the sea-that is, they were marine or euryhyaline.

Department of Geochemistry and Geophysics,

\section{E. Juntus Dasch}

Department of Geology, K. S. W. Campiell

Australian National University,

Canberra, ACT.

Recelved June 16, 1970

1 Faure, G., Hurley, P. M., and Powell, J. L., Geochim. Cosmochim. Asta, 29, 209 (1965)

Murthy, V. R., and Beiser, E., Geochim. Cosmochim. Acta, 32, 1121 (1968).

- Peterman, Z. E., Hedge, C. F., and Tourtelot, H. A., Geochim. Cosmachim. Acta, 84, 105 (1970).

- Faure, G., Hurley, P. M., and Fairbairn, H. W., J. Geophys. Res., 68, 23 (1963)

sasch, E. J., Geochim. Cosmochim. Acta, 88, 1521 (1969)

- Romer, A. S., Notes and Comments on Vertebrate Paleontology (Eniv. of Chicago Press, 1968).

Thomson, K. S., Amer. J. Sci., 267, 457 (1969).

- Denison, R. H., Fieldiana (Geol.), 11, 431 (1956)

- Thomson, K. S., and Campbell, K. S. W., Peabody Mus. Bull. (in the press).

\section{Thermoluminescence of Biological Materials}

ThHRMOLUMTNESChNCE may be observed from many chemical compounds, both in crystalline and in amorphous form. The compounds so far investigated have usually been mineral or synthetic materials, but there is no reason to suppose that the various salts deposited in biological materials have a structure excluding this property.

The bones of vertebrates, in which the mineral salts are deposited as an intercellular substance are one of the best examples. Dr Z. Jaworowski had at his disposal radioactive bones of dinosaurs ${ }^{1}$, and we started off our 